\title{
Body size perception of African women (25-44 years) in Mangaung
}

\section{Francina C Venter*, Corinna M Walsh, Marthinette Slabber \& Christina J Bester*}

\begin{abstract}
OPSOMMING
Oorgewig is een van die mees algemene, dog voorkombare, gesondheidsprobleme in Suid-Afrika, veral onder volwasse swart vroue. Oorgewig word met ' $n$ verskeidenheid van patalogiese toestande, onder andere hipertensie, tipe-2 diabetes mellitus, kardiovaskulêre siektes en vroetydige dood, geassosieer. 'n Verwesterde leefstyl onder inwoners van ontwikkelende lande lei dikwels tot veranderinge in eetgewoontes en gevolglik toenemende vlakke van vetsug.
\end{abstract}

Vroue in laer sosio-ekonomiese klasse is drie- tot ses maal meer geneig tot oorgewig as dié met hoër sosio-ekonomiese status, ongeag etnisiteit. 'n Aantal faktore beïnvloed liggaamsgroottepersepsie, inlsuitend kultuur, sosio-ekonomiese status, sosiale persepsie van vetsug, en die persepsie van gesondheid en gewig in verhouding tot liggaamsgrootte. Volgens omvangryke navorsingsbevindings is ' $\mathrm{n}$ groter liggaamsbou onder swart vroue kultureel meer aanvaarbaar en spreek van goeie gesondheid, finansiële welvaart, seksualiteit, waardigheid, aantreklikheid, verhoogde funksionaliteit, en afwesigheid van infeksie met die menslike immuungebrek-virus (MIV).

Die primêre doel van hierdie studie was om insig te verkry ten opsigte van die persepsie van liggaamsgrootte onder swart vroue in die Mangaungarea, sentraal-Vrystaat. ' $n$ Verteenwoordigende steekproef van 500 swart vroue in twee ouderdomsgroepe (25-34 en 35-44 jaar) is ewekansig vir die studie gekies. Die studie het oor 25 weke gestrek, waartydens 20 deelnemers elke week ingesluit is. Deelnemers se beskouing van vetsug, tot watter mate hulle persoonlike beskouing dié van die algemene populasie verteenwoordig, en hulle houding teenoor gewigsbeheer is ondersoek.

Antropometriese data, wat vetpersentasie, heupmiddelverhouding, gewig en lengte ingesluit het, is versamel. 'n Liggaamsmassa-indeks groter as $25 \mathrm{~kg} /$ $\mathrm{m}^{2}$ is by meer as $50 \%$ van die teikenpopulasie aangetoon. ('n Liggaamsmassa-indeks van $20<25 \mathrm{~kg} /$ $\mathrm{m}^{2}$ word as verteenwoordigend van ' $\mathrm{n}$ normale ligaamsmassa beskou.) Liggaamsgroottepersepsie is bepaal deur die deelnemers se reaksie op 'n reeks van vyf foto's, verteenwoordigend van vyf berekende liggaamsmassa-indekskategorieë, te evalueer. Ongeveer $30 \%$ van die respondente het die oormassa liggaam as die gesondste sowel as die mees welgestelde beskou.

Alhoewel vetsug oorwegend as gesond beskou is, het die meeste deelnemers aangedui dat dit nie aantreklik is nie. Ongeveer $30 \%$ van die deelnemers het die foto verteenwoordigend van 'n laer-asnormale liggaamsmassa-indeks as die mees aantreklike voorkoms gekies. Slegs $8 \%$ van die jonger vroue en $12 \%$ van die ouer vroue het die foto verteenwoordigend van ' $n$ ondergewig voorkoms as mees aantreklik aangedui. Meer as $60 \%$ van albei ouderdomsgroepe het gevoel dat die gemeenskappe waartoe hulle behoort, 'n ondergewig persoon onaantreklik sal vind. ' $n$ Skraal liggaamsbou word met armoede, onderliggende siekte of emosionele ongesteldheid geassosieer.

Die liggaamsgroottepersepsie van respondente en meegaande tevredenheid met groter liggaamsmassa, beïnvloed na alle waarskynlikheid eetgedrag. In teenstelling met die Westerse beskouing, was hierdie populasie nie gemotiveerd om hul eetgedrag ter wille van gesondheidsoorwegings te beheer nie, aangesien hulle nie gesondheidsprobleme as verwant aan liggaamsgrootte beskou nie. Kultuur oefen nog steeds ' $n$ sterk invloed op die populasie se houding teenoor gewigsbeheer uit. Toekomstige programme om vetsug onder swart Suid-Afrikaanse vroue te bestuur, behoort kulturele, sosiale en sosio-ekonomiese aspekte as ' $n$ integrale deel van gesondheidsopvoeding aan te spreek.

\section{- Mrs FC Venter}

Department of Clothing and Fashion Central University of Technology, Free State Bloemfontein

Tel: $+27(0) 515073345$

Fax: +27(0)515073293

Email:ventern@cut.ac.za

${ }^{*}$ Corresponding author

\section{- Prof CM Walsh}

Department of Human Nutrition

University of the Free State

\section{- Prof M Slabber}

Department of Human Nutrition

University of the Free State

\section{- Mrs CJ Bester}

Department of Biostatistics University of the Free State 


\section{INTRODUCTION}

Obesity is one of the most prevalent, yet preventable, health problems in South Africa, especially among adult African women (Hoffman et al, 1997; Walker \& Segal, 1997; Maclntyre, 1998:451-492; Kalk, 2001). Obesity is associated with a wide range of pathological conditions such as hypertension, type-2 diabetes mellitus, cardiovascular disease and early death (Lean et al, 1998; Björntorp, 2001; Popkin, 2001; Goedecke et al, 2006:65-79).

Nutritional patterns of the African population seem to be changing simultaneously with the adoption of a western lifestyle. They adopt the western eating habits and thus increasing levels of obesity occur in developing countries (Chabi et al, 1998; Kim et al, 2000; Popkin, 2001).

People differ in terms of their observations of their worlds - politics and religious difference bearing testimony to this. People also don't see their physical surroundings in a similar light: for example, a perception discrepancy can be found when comparing how overweight people see themselves and how other people see the overweight person's body. Puoane et al (2002) postulates that, in South Arica, women have inaccurate perceptions of their body weight. In a demographic and health survey these researchers found that only $16 \%$ of overweigh black South African women perceived themselves as overweight.

A number of factors can affect body size perceptions. These factors include culture, socio-economic status, social perception of obesity, perceptions of overweight individuals and perception of health and weight related to body size. According to a considerable body of research, African women with a larger size appear to be culturally more acceptable, portraying a symbol of health, financial wealth, sexuality, dignity, attractiveness, increased functional capacity, and absence of the human immunodeficiency virus (HIV) (Prentice, 2000; Reboussin et al, 2000). According to various studies done in South Africa (Kruger et al, 1994; Clark et al, 1999; Mvo et al, 1999) overweight African women also appeared to be culturally more acceptable, portraying a symbol of prosperity and dignity.

In contrast to the white experience of feeling pressurised to be thin, black women described feelings of being influenced by friends and family to maintain a larger body size (Powell \& Kahn, 1995; Puoane et al, 2005). They were cautioned not to lose too much weight, or told they looked too thin, or that they looked just fine being heavier.

Ethnic differences have also been documented in relation to weight perception and weight loss behaviour. Overweight black women were generally more satisfied with their appearance than white women. Therefore, factors other than body size per se might influence black women's overall evaluation of their appearance. Investigators (Kumanyika et al, 1993; Stevens et al, 1994) have found that black women consider themselves attractive even though they feel dissatisfied with their body size. In a study of 500 African-American women, approximately forty percent of the overweight women considered their figures to be attractive or very attractive, indicating a positive body weight perception (Kumanyika et al, 1993).

Recognizing the fact that cultural preoccupation with thinness has increased, researchers have also been interested in the social perception of obesity (Wilfley et al, 1996, Shaw et al, 2004).

Dawson (1988) suggested that Black women do not perceive themselves as overweight because they evaluate their body size not in relation to the white ideal in the media, but in comparison to other black women in their social milieu. In this study we sought to investigate if Black women in Mangaung also complied with Dawson's suggestion. The perceptions of these women on health, weight and attractiveness were measured, as well as their perception on the reaction of the community towards obese and underweight persons. Most of the research concerning body weight perception has been conducted on college-age students (Cash \& Pruzinsky, 2002:509-516). Consequently, it would be of interest to investigate the differences in body size perception of older and younger Black women as well as the body size perception of the respondents in relation to their BMI.

\section{METHODOLOY}

\section{Photographs and Questionnaire used}

The instrument comprised a set of photographs and a questionnaire.

Photographs A graded set of photographs with calculated BMl's was developed using a modification of the distorting photograph technique (Massara \& Stunkard, 1979). A black female volunteer with a known body mass index falling within the normal range $(22,7 \mathrm{~kg} / \mathrm{m} 2)$ was photographed. The picture was scanned and then distorted using the computer program L View Proã (1993-1996) to produce images that were both thinner and wider than the original. The height of the figure remained the same while the breadth was resized. In order not to reduce or enlarge the size of the figures beyond reality, only five photographs were used instead of the entire series. The five photographs (Fig 1) were selected to illustrate a range of five BMl's, namely underweight $(<18,5 \mathrm{~kg} / \mathrm{m} 2)$, a lower range of normal weight $(18,5-19,9 \mathrm{~kg} / \mathrm{m} 2)$, a higher range of normal weight $(20-24,9 \mathrm{~kg} / \mathrm{m} 2)$, overweight $(25-29,9 \mathrm{~kg} / \mathrm{m} 2)$ and obese $(>30 \mathrm{~kg} / \mathrm{m} 2)$. Validity of the photographs was tested by 21 experts who viewed the photographs in random order and assigned a BMI value to each. An expert was defined as a registered dietician who had treated underweight, overweight and obese patients for more than one year in a private practice or hospital setting. Statistical analyses were conducted by the Department of Biostatistics using the Statistical Analysis System (SAS/STAT®, 1989:943). The number and percentage of experts who classified each photograph was calculated, and the BMI assigned to each photograph was described by the mean and standard deviation. In addition, 95\% confi- 
dence intervals (Cl) were calculated (Altman, 1999). Validation of those photographs that had lower and upper ranges of BMI (not the photographs depicting underweight and obese) was done by $95 \%$ limits of agreement to measure how closely $95 \%$ of all experts would gauge each range.

Classification of photographs by experts The classification of photographs by experts is summarised in Table 1. All experts classified the photographs in the correct order and estimated the BMI average for photographs 1 through 5 as $17,19,9,24$, 28,6 and $35,9 \mathrm{~kg} / \mathrm{m} 2$ respectively. The $95 \%$ confidence intervals indicated that for all photographs except photograph 2 , the mean value assigned by experts fell within the correct range. For photograph 2, seven experts rated the BMI correctly to fall within the range of 18,5-19,9. Eight experts rated the BMI of photograph 2 as 20,0, thus differing from the upper limit of 19,9 by 0,1 . Only six experts rated the BMI of photograph 2 higher than 20,0. The maximum difference (all from the same expert) was 2,1 for photographs 2,3 and 4 .

The questionnaire The structured questionnaire, compiled after a literature review, was used in a previous study that determined the body size perceptions of female first-year university students (Slabber et al, 2000). The first part of the questionnaire included questions relating to health, weight and attractiveness. The second part covered questions on how the respondents perceived th community's reactions towards an overweight and underweight person. The questionnaire, used in conjunction with the photographs, was used in a larger study that investigated the nutritional health of 500 randomly chosen premenopausal black women, aged between 25 and 44 years, from Mangaung (Free State, South Africa).

The reliability of questions on body size perception is summarised in Table 2. The answers obtained from the two interviews were evaluated, and the questions with conflicting answers exceeding $20 \%$ were considered unreliable.

\section{Research procedure}

Over a period of 25 weeks, 20 women were interviewed once a week. Subjects were weighed barefoot in an examination gown to the nearest 0,1 kilogram $(\mathrm{kg})$ using a digital electronic scale. Height was determined to the nearest 0,5 centimetres $(\mathrm{cm})$ by using a stadiometer. During measurements, subjects were standing upright against a flat surface with the head in the Frankfort plane position.

The photographs were shown during the individual interviews. One trained researcher conducted all the interviews with the aid of a Sesotho interpreter. The five photographs were placed randomly at eye level before the participant. While the photographs were being viewed, the researcher interviewed the partici-

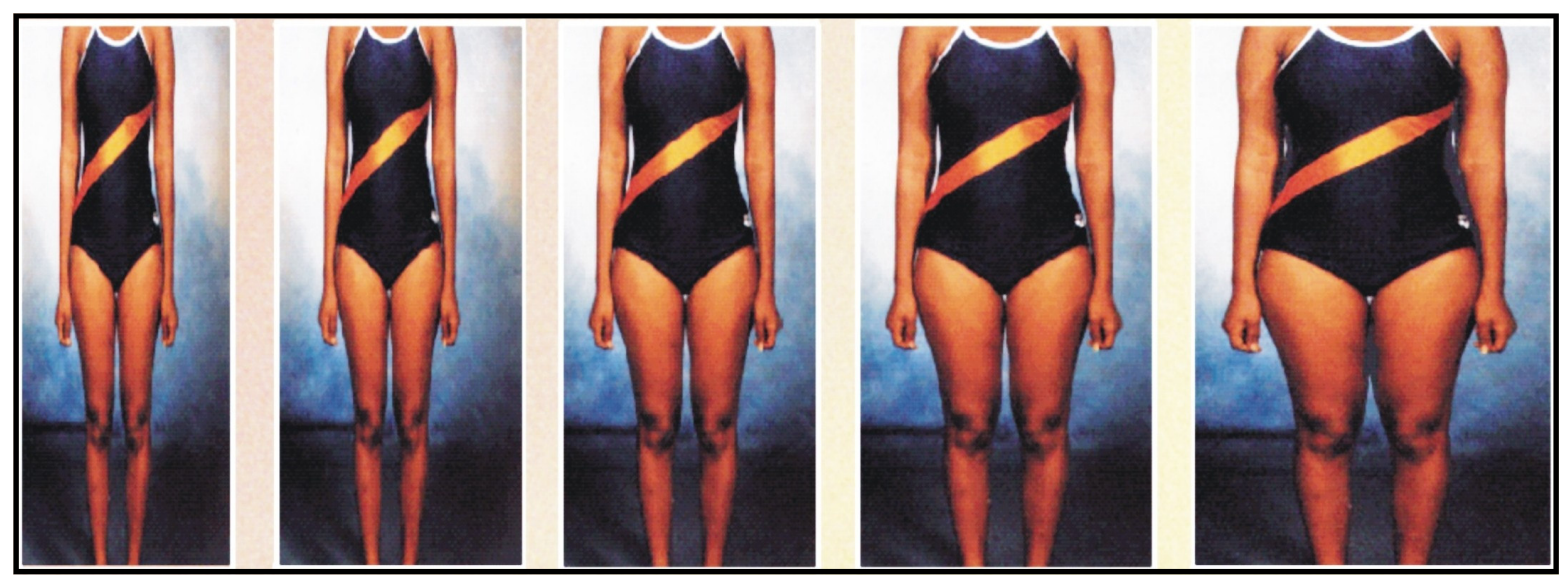

FIGURE 1: BODY FIGURES

TABLE 1: CLASSIFICATION OF PHOTOGRAPHS BY EXPERTS $(\mathrm{N}=21)$

\begin{tabular}{|c|c|c|c|c|c|}
\hline & $\begin{array}{l}\text { Photograph } 1 \\
\left(<18,5 \mathrm{~kg} / \mathrm{m}^{2}\right)\end{array}$ & \begin{tabular}{|c|}
$\begin{array}{c}\text { Photograph } 2 \\
\left(18,5-19,9 \mathrm{~kg} / \mathrm{m}^{2}\right)\end{array}$ \\
\end{tabular} & \begin{tabular}{|c|} 
Photograph 3 \\
$\left(20,0-24,9 \mathrm{~kg} / \mathrm{m}^{2}\right)$ \\
\end{tabular} & $\begin{array}{c}\text { Photograph } 4 \\
\left(25,0-29,9 \mathrm{~kg} / \mathrm{m}^{2}\right) \\
\end{array}$ & $\begin{array}{c}\text { Photograph } 5 \\
\left(\geq 30 \mathrm{~kg} / \mathrm{m}^{2}\right)\end{array}$ \\
\hline Number correct & $20(95 \%)$ & $7(33 \%)$ & $14(67 \%)$ & $14(67 \%)$ & $21(100 \%)$ \\
\hline Number incorrect & $1(5 \%)$ & $14(67 \%)$ & $7(33 \%)$ & $7(33 \%)$ & 0 \\
\hline Number differing by more than $0,1 \mathrm{~kg} / \mathrm{m}^{2}$ & 0 & $6(28,6 \%)$ & $2(9,5 \%)$ & $2(9,5 \%)$ & 0 \\
\hline Maximum difference ${ }^{*}$ & 0 & 2,1 & 2,1 & 2,1 & 0 \\
\hline Average & 17 & 19,9 & 24 & 28,6 & 35,9 \\
\hline Standard deviation & 2,3 & 1,05 & 1,45 & 1,63 & 3,15 \\
\hline $95 \%$ Confidence interval & 15,$9 ; 18,1$ & 19,$4 ; 20,4$ & 27,$9 ; 29,3$ & 23,$3 ; 24,7$ & 34,$5 ; 37,3$ \\
\hline $95 \%$ Limits of agreement ${ }^{\star *}$ & 14,$7 ; 19,3$ & 17,$8 ; 22,0$ & 21,$1 ; 26,9$ & 25,$3 ; 31,9$ & 29,$6 ; 42,2$ \\
\hline
\end{tabular}

* The same expert

** Range within which $95 \%$ of all experts will classify this photograph 
TABLE 2: BODY SIZE PERCEPTION QUESTIONNAIRE AND PERCENTAGE DIFFERING ON REPETITION

\begin{tabular}{|ll|c|}
\hline Questions & \% differing \\
\hline $1 \quad$ Which person looks the healthiest? & 14,2 \\
\hline $2 \quad$ Which person's body is the most attractive? & 14,2 \\
\hline $3 \quad$ Indicate which photos belong to the following categories: & 10,2 \\
\hline A Female fat (overweight). & 4,1 \\
\hline B Female normal (acceptable). & 4,1 \\
\hline C Female slim (underweight). & 10,2 \\
\hline What is the reaction of your community towards somebody that looks like photograph 5*? & 6,1 \\
\hline A Think they are rich. & 8,2 \\
\hline B Think they are healthy. & 8,4 \\
\hline C Think they are attractive. & 22,5 \\
\hline D Think they are the same as other people. & 36,7 \\
\hline E $\quad$ Think they are lazy and do not like them. & 18,4 \\
\hline F $\quad$ Avoid them socially. & \\
\hline G Laugh at them. & \\
\hline What is the reaction of your community towards somebody who looks like photograph 1**? & 4,1 \\
\hline A $\quad$ Think they are rich. & 6,1 \\
\hline B $\quad$ Think they are healthy. & 8,1 \\
\hline C $\quad$ Think they are attractive. & 14,3 \\
\hline D $\quad$ Think they are the same as other people. & 12,2 \\
\hline E $\quad$ Think they are lazy and do not like them. & 38,8 \\
\hline F $\quad$ Avoid them socially. & 20,4 \\
\hline G Laugh at them. & \\
\hline
\end{tabular}

* Photograph 5 - obese body size

** Photograph 1 - underweight body size

pant using the structured questionnaire. The participant was asked to indicate the body size that best represented the following states: healthy, an attractive body, normal (acceptable) body size, fat (overweight, obese), and too slim (underweight). The participants' perceptions of the community's attitude were determined by their response to the photographs that represented underweight $(\mathrm{BMl}<18,5)$ and obese (BMI>30) women.

A pilot study was performed on a group of twenty African pre-menopausal women who were not part of the selected sample. It was determined that the photographs should be placed in random order to ensure that the respondents did not always choose the first photograph as the most underweight and the last photograph as the most obese.

All participants gave written informed consent and the Ethics Committee of the Faculty of Health Sciences, University of the Free State, approved the study.

\section{Data analysis}

The data were categorised into two age groups: 2534 years and $35-44$ years. For each group, continuous variables were described by means and standard deviations, or medians and percentiles as applicable.
Frequencies and percentages described categorical variables.

The data were also categorised into one of three weight groups, namely normal weight, overweight and obese and associations between weight status and perceptions were calculated using Chi-squared and Fishers Exact test $p$-values with a significance of $p$ $<0,05$.

\section{RESULTS}

\section{Body mass index (BMI)}

Table 3 shows the body mass index (BMI) of the African women aged between 25 and 44 years.

The body mass index (BMI) of a large percentage $(38 \%)$ of the subjects fell in the normal weight category: An even higher percentage $(52,7 \%)$ of subjects were overweight or obese therefore most subjects fell in the overweight and obese BMI categories.

\section{Perceptions of health, weight and attractiveness}

Table 4 shows the reaction of respondents to the photographs concerning health, weight and attractiveness. 
TABLE 3: BODY MASS INDEX OP PARTICIPANTS

\begin{tabular}{|l|r|r|}
\hline \multirow{2}{*}{ BMI Category } & \multicolumn{2}{|c|}{$\begin{array}{c}\text { 25-44 years } \\
\text { (n=496) }\end{array}$} \\
\cline { 2 - 3 } & $\mathbf{n}$ & \multicolumn{1}{c|}{$\%$} \\
\hline Underweight: $<18,5 \mathrm{~kg} / \mathrm{m}^{2}$ & 16 & 3,2 \\
\hline Lower normal weight: $18,5<20 \mathrm{~kg} / \mathrm{m}^{2}$ & 31 & 6,3 \\
\hline Normal weight: $20<25 \mathrm{~kg} / \mathrm{m}^{2}$ & 187 & 37,8 \\
\hline Overweight: $25<30 \mathrm{~kg} / \mathrm{m}^{2}$ & 144 & 29,1 \\
\hline Obese: $\geq 30 \mathrm{~kg} / \mathrm{m}^{2}$ & 117 & 23,6 \\
\hline
\end{tabular}

TABLE 4: SUBJECTS' PERCEPTIONS OF HEALTH, HEALTHY WEIGHT AND ATTRACTIVENESS IN RESPONSE TO PHOTOGRAPHS DEPICTING FIVE BMI CATEGORIES ( $\mathrm{N}=495)$

\begin{tabular}{|c|c|c|c|c|c|c|}
\hline \multirow[b]{2}{*}{$\begin{array}{l}\text { Question } \\
\text { Which person looks: }\end{array}$} & & \multicolumn{5}{|c|}{ BMI Categories } \\
\hline & & Underweight & $\begin{array}{l}\text { Lower normal } \\
\text { weight }\end{array}$ & Normal weight & Overweight & Obese \\
\hline \multirow[b]{2}{*}{ The healthiest? } & $\mathrm{n}$ & 48 & 126 & 69 & 150 & 102 \\
\hline & $\%$ & 9,8 & 25,4 & 14 & 30,1 & 20,7 \\
\hline \multirow[b]{2}{*}{ Overweight? } & $n$ & 1 & 7 & 10 & 41 & 436 \\
\hline & $\%$ & 0,2 & 1,4 & 2,0 & 8.2 & 88,2 \\
\hline \multirow[b]{2}{*}{ Acceptable (normal weight)? } & $\mathrm{n}$ & 70 & 135 & 137 & 145 & 8 \\
\hline & $\%$ & 14,1 & 27,2 & 27,6 & 29,3 & 1,8 \\
\hline \multirow[b]{2}{*}{ Underweight? } & $\mathrm{n}$ & 434 & 41 & 9 & 12 & 0 \\
\hline & $\%$ & 87,5 & 8,3 & 1,8 & 2,4 & 0 \\
\hline \multirow[b]{2}{*}{ The most attractive? } & $\mathrm{n}$ & 46 & 148 & 108 & 135 & 58 \\
\hline & $\%$ & 9,2 & 29,9 & 21,9 & 27,2 & 11,8 \\
\hline
\end{tabular}

TABLE 5: THE REACTION OF THE COMMUNITY TOWARDS OBESE AND UNDERWEIGHT PERSONS AS PERCEIVED BY THE PARTICIPANTS ( $\mathrm{N}=495)$

\begin{tabular}{|l|c|c|c|c|c|c|c|c|}
\hline & \multicolumn{9}{|c|}{ What is the reaction of your community towards } \\
\hline & \multicolumn{3}{|c|}{ an obese (BMI $\mathbf{3 0} \mathbf{~ k g} / \mathbf{m}^{2}$ ) person? } & \multicolumn{2}{c|}{ an underweight : (<18,5 kg/m $\left.\mathbf{m}^{2}\right)$ person? } \\
\hline \multicolumn{1}{|c|}{ They think they are } & \multicolumn{2}{|c|}{ Yes } & \multicolumn{2}{c|}{ No } & \multicolumn{2}{c|}{ Yes } & \multicolumn{3}{c|}{ No } \\
\hline & $\mathbf{n}$ & $\%$ & $\mathbf{n}$ & $\%$ & $\mathbf{n}$ & $\%$ & $\mathbf{n}$ & $\%$ \\
\hline rich & 242 & 48,6 & 253 & 51,2 & 97 & 19,6 & 398 & 80,2 \\
\hline healthy & 263 & 52,8 & 232 & 47 & 176 & 35,5 & 319 & 64,3 \\
\hline attractive & 202 & 40,2 & 293 & 59,3 & 179 & 36 & 316 & 63,7 \\
\hline the same as other people & 236 & 47,4 & 26 & 52,4 & 299 & 46,2 & 266 & 53,7 \\
\hline rich & 242 & 48,6 & 253 & 51,2 & 97 & 19,6 & 398 & 80,2 \\
\hline
\end{tabular}

Healthy appearance When asked which person appeared to be the healthiest, $25,4 \%$ of the respondents chose the lower normal weight (BMI of $18,5<20$ $\mathrm{kg} / \mathrm{m} 2)$. The largest percentage $(30 \%)$ of respondents chose the overweight person as representing the healthiest image.

Acceptable weight When asked, "Which person looks acceptable?" a fairly high percentage $(29,3 \%)$ respondents chose overweight while $27,6 \%$ and $27,2 \%$ chose normal and lower normal weight respectively.

Attractiveness Almost one-third of the respondents $(30 \%)$ chose the lower normal weight as the most attractive body. In addition, $27,2 \%$ women also chose the overweight BMI as attractive. Very few
$(9,2 \%)$ women chose underweight as being the most attractive.

Perceptions of respondents of how the community views underweight and overweight persons

Table 5 represents the respondents' views when asked to indicate how their community viewed the photographs depicting obese and underweight people (either rich, healthy, attractive, or the same as other people). When asked whether the community viewed an obese person as rich or not, $48,6 \%$ of women responded that obese people were viewed as rich, while $51,2 \%$ disagreed. More than half of the women $(52,8 \%)$ thought that obese people were healthy. With regard to obesity and attractiveness, most women $(59,3 \%)$ viewed obese persons as less attractive in 
the eyes of the community. The percentage of women who considered the community to view obese people the same as other people, was $47,4 \%$.

The same questions were asked about the body size photographs representing an underweight individual. When asked whether the community viewed slim people as being rich, the vast majority of women $(80,2 \%)$ responded that the community did not view slim people as being wealthy. The majority of respondents also indicated that the underweight body size was considered unhealthy $(64,3 \%)$.

Perceptions of health, weight and attractiveness related to age of respondents

Table 6 shows the reaction of respondents to the photographs concerning health, weight and attractiveness.

Healthy appearance When asked which person appeared to be the healthiest, $28,6 \%$ of the older respondents chose the lower normal weight (BMI of $18,5<20 \mathrm{~kg} / \mathrm{m} 2)$. The largest percentage of respondents in both age groups $(31,3 \%$ and $29 \%$ of the younger and older participants, respectively) chose the overweight person as representing the healthiest image.

Acceptable weight When asked, "Which person looks acceptable?" the largest percentage of respondents in the younger group $(31,3 \%)$ chose normal weight, while $33,6 \%$ of the older group chose $t$ lower normal weight. A fairly high percentage of the younger group also chose lower normal weight $(22,3 \%)$ and overweight $(28,4 \%)$, while the older group chose normal weight $(23,1 \%)$ and overweight $(30,4 \%)$. More women indicated that overweight bodies were healthy, but that the lower normal weight seemed more attractive.
Attractiveness Almost one-third of the respondents $(29,1 \%$ of younger women and $30,9 \%$ of older women) chose lower normal weight as the most attractive body. In addition, $24,8 \%$ and $27 \%$ of the younger women also chose normal weight and overweight, respectively. In the older group, $27,6 \%$ of women chose overweight as being most attractive. Very few $(7,6 \%$ of the younger and $11,5 \%$ of the older women) chose underweight as being the most attractive.

The only statistically significant differences between the younger and older groups were that a larger percentage of the younger women viewed normal weight as the healthiest $(p=0,0156)$, as well as acceptable $(p=0,0049)$, whereas a large percentage of the older women viewed the underweight as underweight $(p=0,0329)$, and the lower normal weight as acceptable $(p=0,0417)$.

Perceptions of respondents in two age groups of how the community views underweight and overweight persons

Table 7 represents the respondents' perceptions about how their community viewed the obese and underweight people (either rich, healthy, attractive, or the same as other people). When asked whether the community judged an obese person to be rich or not, $47,8 \%$ of younger women responded that obese people were judged to be rich, while $52 \%$ disagreed. In the group of older women these differences were smaller $(49,8 \%$ and $50,2 \%$, respectively). More than half of the younger women's $(55 \%)$ perceptions were that the community will see obese people to be healthy. With regard to attractiveness, most women in both the younger $(60,4 \%)$ and the older $(58,1 \%)$ groups thought that their community viewed obese persons as less attractive.

\section{TABLE 6: SUBJECTS' PERCEPTIONS OF HEALTH, WEIGHT AND ATTRACTIVENSS IN RESPONSE TO PHOTOGRAPHS DEPICTING FIVE BMI CATEGORIES}

\begin{tabular}{|c|c|c|c|c|c|c|c|c|c|c|c|}
\hline \multirow{3}{*}{\multicolumn{2}{|c|}{$\frac{\text { Question }}{\text { Which person looks: }}$}} & \multicolumn{10}{|c|}{ BMI Categories } \\
\hline & & \multicolumn{2}{|c|}{ Underweight } & \multicolumn{2}{|c|}{$\begin{array}{l}\text { Lower normal } \\
\text { weight }\end{array}$} & \multicolumn{2}{|c|}{ Normal weight } & \multicolumn{2}{|c|}{ Overweight } & \multicolumn{2}{|c|}{ Obese } \\
\hline & & $\begin{array}{c}Y^{*} \\
(n=278)\end{array}$ & $\begin{array}{c}0^{\#} \\
(n=217)\end{array}$ & $\begin{array}{c}Y \\
(n=278)\end{array}$ & $\begin{array}{c}0 \\
(n=217)\end{array}$ & $\begin{array}{c}Y \\
(n=278)\end{array}$ & $\begin{array}{c}0 \\
(n=217)\end{array}$ & $\begin{array}{c}Y \\
(n=278)\end{array}$ & $\begin{array}{c}0 \\
(n=217)\end{array}$ & $\begin{array}{c}Y \\
(n=278)\end{array}$ & $\begin{array}{c}0 \\
(n=217)\end{array}$ \\
\hline \multirow{2}{*}{ the healthiest? } & $\mathrm{n}$ & 27 & 21 & 64 & 62 & 48 & 21 & 87 & 63 & 52 & 50 \\
\hline & $\%$ & 9,7 & 9,7 & 23,0 & 28,6 & 17,3 & 9,7 & 31,3 & 29 & 18,7 & 23 \\
\hline \multirow[b]{2}{*}{ overweight? } & $\mathrm{n}$ & 1 & 0 & 5 & 2 & 5 & 5 & 22 & 19 & 245 & 191 \\
\hline & $\%$ & 0,4 & 0 & 1,8 & 0,9 & 1,8 & 2,3 & 7,9 & 8,8 & 88,1 & 88 \\
\hline \multirow{2}{*}{$\begin{array}{l}\text { acceptable (normal } \\
\text { weight)? }\end{array}$} & $\mathrm{n}$ & 44 & 26 & 62 & 73 & 87 & 50 & 79 & 66 & 6 & 2 \\
\hline & $\%$ & 15,8 & 12 & 22,3 & 33,6 & 31,3 & 23,1 & 28,4 & 30,4 & 2,2 & 0,9 \\
\hline \multirow{2}{*}{ underweight? } & $\mathrm{n}$ & 236 & 198 & 27 & 14 & 6 & 3 & 9 & 2 & 0 & 0 \\
\hline & $\%$ & 85 & 91,2 & 9,7 & 6,5 & 2,1 & 1,4 & 3,2 & 0,9 & 0 & 0 \\
\hline \multirow{2}{*}{ the most attractive? } & $\mathrm{n}$ & 21 & 25 & 81 & 67 & 69 & 39 & 75 & 60 & 32 & 26 \\
\hline & $\%$ & 7,6 & 11,5 & 29,1 & 30,9 & 24,8 & 17,9 & 27 & 27,6 & 11,5 & 12 \\
\hline
\end{tabular}

${ }^{*} Y=$ younger group

$\# \mathrm{O}=$ older group 
TABLE 7: WHAT THE COMMUNITY THINTKS ABOUT OBESE AND UNDERWEIGHT PERSONS AS PERCEIVED BY THE PARTICIPANTS

\begin{tabular}{|c|c|c|c|c|c|c|c|c|c|c|c|c|c|c|c|c|}
\hline \multirow[b]{5}{*}{ They think they are: } & \multicolumn{16}{|c|}{ What is the reaction of your community towards } \\
\hline & \multicolumn{8}{|c|}{ an obese $\left(\mathrm{BMI} \geq 30 \mathrm{~kg} / \mathrm{m}^{2}\right)$ person? } & \multicolumn{8}{|c|}{ an underweight $\left(\mathrm{BMI} \leq 18,5 \mathrm{~kg} / \mathrm{m}^{2}\right)$ person? } \\
\hline & \multicolumn{4}{|c|}{$\begin{array}{c}25-34 \text { years } \\
(n=278)\end{array}$} & \multicolumn{4}{|c|}{$\begin{array}{c}35-44 \text { years } \\
(n=217)\end{array}$} & \multicolumn{4}{|c|}{$\begin{array}{c}25-34 \text { years } \\
(n=278)\end{array}$} & \multicolumn{4}{|c|}{$\begin{array}{c}35-44 \text { years } \\
(n=217)\end{array}$} \\
\hline & \multicolumn{2}{|c|}{ Yes } & \multicolumn{2}{|c|}{ No } & \multicolumn{2}{|c|}{ Yes } & \multicolumn{2}{|c|}{ No } & \multicolumn{2}{|c|}{ Yes } & \multicolumn{2}{|c|}{ No } & \multicolumn{2}{|c|}{ Yes } & \multicolumn{2}{|c|}{ No } \\
\hline & n & $\%$ & n & $\%$ & n & $\%$ & n & $\%$ & n & $\%$ & n & $\%$ & n & $\%$ & n & $\%$ \\
\hline rich & 133 & 47,8 & 145 & 52,2 & 108 & 49,8 & 109 & 50,2 & 47 & 16,9 & 231 & 83,1 & 50 & 23 & 167 & 77 \\
\hline healthy & 153 & 55 & 125 & 45 & 109 & 50,2 & 108 & 49,8 & 106 & 38,1 & 172 & 61,9 & 70 & 32,3 & 147 & 67,7 \\
\hline attractive & 110 & 39,6 & 168 & 60,4 & 91 & 41,9 & 126 & 58,1 & 106 & 38,1 & 172 & 61,9 & 73 & 33,6 & 144 & 66,4 \\
\hline the same as other people & 131 & 47,1 & 147 & 52,9 & 104 & 47,9 & 113 & 52,1 & 128 & 46 & 150 & 54 & 101 & 46,5 & 116 & 53,5 \\
\hline
\end{tabular}

TABLE 8: PERCEPTIONS OF HEALTH, WEIGHT \& ATTRACTIVENESS RELATED TO THREE BMI GROUPS OF RESPONDENTS

\begin{tabular}{|c|c|c|c|c|c|c|c|}
\hline \multirow{3}{*}{\multicolumn{2}{|c|}{$\begin{array}{l}\text { Question } \\
\text { Which person looks: } \\
\text { Chi-squared p-value }\end{array}$}} & \multicolumn{6}{|c|}{ BMI Categories of respondents } \\
\hline & & \multicolumn{2}{|c|}{$\begin{array}{c}\text { Normal weight } \\
(n=218)\end{array}$} & \multicolumn{2}{|c|}{$\begin{array}{l}\text { Overweight } \\
(n=143)\end{array}$} & \multicolumn{2}{|c|}{$\begin{array}{c}\text { Obese } \\
(n=117)\end{array}$} \\
\hline & & $\mathrm{n}$ & $\%$ & $\mathbf{n}$ & $\%$ & $\mathrm{n}$ & $\%$ \\
\hline $\begin{array}{l}\text { the healthiest? } \\
\text { Photo 1: }<18,5 \mathrm{~kg} / \mathrm{m}^{2} \\
\text { Photo 2: } 18,5<20 \mathrm{~kg} / \mathrm{m}^{2} \\
\text { Photo 3: } 25<30 \mathrm{~kg} / \mathrm{m}^{2} \\
\text { Photo 4: } 20<25 \mathrm{~kg} / \mathrm{m}^{2} \\
\text { Photo } 5: \geq 30 \mathrm{~kg} / \mathrm{m}^{2}\end{array}$ & $\begin{array}{c}p \\
0,0661\end{array}$ & $\begin{array}{l}23 \\
55 \\
38 \\
58 \\
44\end{array}$ & $\begin{array}{c}10,55 \\
25,2 \\
17,43 \\
26,61 \\
20,18\end{array}$ & $\begin{array}{c}6 \\
43 \\
17 \\
48 \\
29\end{array}$ & $\begin{array}{c}4,20 \\
30,07 \\
11,89 \\
33,57 \\
20,28\end{array}$ & $\begin{array}{l}16 \\
23 \\
13 \\
41 \\
24\end{array}$ & $\begin{array}{l}13,68 \\
19,66 \\
11,11 \\
35,04 \\
20,51\end{array}$ \\
\hline $\begin{array}{l}\text { overweight? } \\
\text { Photo 1: }<18,5 \mathrm{~kg} / \mathrm{m}^{2} \\
\text { Photo 2: } 18,5<20 \mathrm{~kg} / \mathrm{m}^{2} \\
\text { Photo 3: } 25<30 \mathrm{~kg} / \mathrm{m}^{2} \\
\text { Photo 4: } 20<25 \mathrm{~kg} / \mathrm{m}^{2} \\
\text { Photo } 5: \geq 30 \mathrm{~kg} / \mathrm{m}^{2}\end{array}$ & 0,7630 & $\begin{array}{c}0 \\
4 \\
4 \\
18 \\
192\end{array}$ & $\begin{array}{c}0 \\
1,83 \\
1,83 \\
8,26 \\
88,07\end{array}$ & $\begin{array}{c}1 \\
2 \\
3 \\
14 \\
123\end{array}$ & $\begin{array}{c}0,70 \\
1,40 \\
2,10 \\
9,79 \\
86,01\end{array}$ & $\begin{array}{c}0 \\
1 \\
1 \\
7 \\
108\end{array}$ & $\begin{array}{c}0,00 \\
0,85 \\
0,85 \\
5,98 \\
92,31\end{array}$ \\
\hline $\begin{array}{l}\text { acceptable (normal weight)? } \\
\text { Photo 1: }<18,5 \mathrm{~kg} / \mathrm{m}^{2} \\
\text { Photo 2: } 18,5<20 \mathrm{~kg} / \mathrm{m}^{2} \\
\text { Photo 3: } 25<30 \mathrm{~kg} / \mathrm{m}^{2} \\
\text { Photo 4: } 20<25 \mathrm{~kg} / \mathrm{m}^{2} \\
\text { Photo 5: } \geq 30 \mathrm{~kg} / \mathrm{m}^{2}\end{array}$ & $0,0142^{*}$ & $\begin{array}{c}33 \\
48 \\
64 \\
68 \\
5\end{array}$ & $\begin{array}{c}15,14 \\
22,02 \\
29,36 \\
31,19 \\
2,29\end{array}$ & $\begin{array}{c}23 \\
54 \\
27 \\
37 \\
2\end{array}$ & $\begin{array}{c}16,08 \\
37,76 \\
18,88 \\
25,87 \\
1,40\end{array}$ & $\begin{array}{c}13 \\
25 \\
40 \\
38 \\
1\end{array}$ & $\begin{array}{r}11,11 \\
21,37 \\
34,19 \\
32,48 \\
0,85\end{array}$ \\
\hline $\begin{array}{l}\text { underweight? } \\
\text { Photo 1: }<18,5 \mathrm{~kg} / \mathrm{m}^{2} \\
\text { Photo 2: } 18,5<20 \mathrm{~kg} / \mathrm{m}^{2} \\
\text { Photo 3: } 25<30 \mathrm{~kg} / \mathrm{m}^{2} \\
\text { Photo 4: } 20<25 \mathrm{~kg} / \mathrm{m}^{2} \\
\text { Photo 5: } \geq 30 \mathrm{~kg} / \mathrm{m}^{2} \\
\end{array}$ & 0,2579 & $\begin{array}{c}193 \\
16 \\
4 \\
5 \\
0 \\
\end{array}$ & $\begin{array}{c}88,53 \\
7,34 \\
1,83 \\
2,29 \\
0,00 \\
\end{array}$ & $\begin{array}{c}119 \\
7 \\
5 \\
2 \\
0 \\
\end{array}$ & $\begin{array}{c}83,22 \\
11,89 \\
3,50 \\
1,40 \\
0,00 \\
\end{array}$ & $\begin{array}{c}107 \\
8 \\
0 \\
2 \\
0 \\
\end{array}$ & $\begin{array}{r}91,45 \\
6,84 \\
0,00 \\
1,71 \\
0,00 \\
\end{array}$ \\
\hline $\begin{array}{l}\text { the most attractive? } \\
\text { Photo 1: }<18,5 \mathrm{~kg} / \mathrm{m}^{2} \\
\text { Photo 2: } 18,5<20 \mathrm{~kg} / \mathrm{m}^{2} \\
\text { Photo 3: } 25<30 \mathrm{~kg} / \mathrm{m}^{2} \\
\text { Photo 4: } 20<25 \mathrm{~kg} / \mathrm{m}^{2} \\
\text { Photo 5: } \geq 30 \mathrm{~kg} / \mathrm{m}^{2} \\
\end{array}$ & 0,8187 & $\begin{array}{l}19 \\
68 \\
43 \\
58 \\
30\end{array}$ & $\begin{array}{c}8,72 \\
31,19 \\
19,72 \\
26,61 \\
13,46 \\
\end{array}$ & $\begin{array}{l}12 \\
39 \\
33 \\
44 \\
15\end{array}$ & $\begin{array}{c}8,39 \\
27,27 \\
23,08 \\
30,77 \\
10,49\end{array}$ & $\begin{array}{l}11 \\
38 \\
29 \\
28 \\
11\end{array}$ & $\begin{array}{r}9,40 \\
32,48 \\
24,79 \\
23,93 \\
9,40\end{array}$ \\
\hline
\end{tabular}

The same questions were asked about an underweight individual. When asked whether the community viewed slim people to be rich, the vast majority of younger $(83,1 \%)$ and older women $(77 \%)$ thought that the community did not view slim people as being wealthy. The majority of respondents also indicated that the underweight body size was considered unhealthy $(61,9 \%$ of younger women and $67,7 \%$ of older women). The view that underweight was considered to be less attractive was expressed by $61,9 \%$ of the younger group and $66,4 \%$ of the older group. These results corresponded I with the feedback obtained when respondents were asked to choose the photo- graph that depicted the most attractive body. Very few ( $7,6 \%$ of younger women and $11,5 \%$ of older women) felt that underweight was most attractive.

In both age groups significantly higher percentages of respondents viewed the obese person as rich and healthy $(p<0,0002)$ compared to the underweight person. No significant differences were found between the two age groups.

Perceptions of health, weight and attractiveness related to $\mathrm{BMI}$ of the respondents 
TABLE 9: PERCEPTIONS OF THE RESPONDENTS ABOUT THE REACTION TOWARDS OBESE AND UNDERWEIGHT PERSONS RELATED TO BMI OF RESPONDENTS

\begin{tabular}{|c|c|c|c|c|c|c|c|c|}
\hline \multirow{2}{*}{\multicolumn{2}{|c|}{\begin{tabular}{|l|} 
\\
What is the reaction of your community towards: \\
an obese $\left(\mathrm{BMI} \geq 30 \mathrm{~kg} / \mathrm{m}^{2}\right)$ person?
\end{tabular}}} & \multicolumn{7}{|c|}{ BMI Categories of respondents } \\
\hline & & \multicolumn{3}{|c|}{$\begin{array}{l}\text { Normal weight } \\
(n=218)\end{array}$} & \multicolumn{2}{|c|}{$\begin{array}{l}\text { Overweight } \\
(n=143)\end{array}$} & \multicolumn{2}{|c|}{$\begin{array}{c}\text { Obese } \\
(n=117)\end{array}$} \\
\hline They think they are: & $p$ & & YES & NO & YES & NO & YES & NO \\
\hline rich & 0,3161 & $\%$ & $\begin{array}{r}112 \\
51,38\end{array}$ & $\begin{array}{r}106 \\
48,62\end{array}$ & $\begin{array}{r}68 \\
47,55\end{array}$ & $\begin{array}{r}75 \\
52,45\end{array}$ & $\begin{array}{r}50 \\
42.74\end{array}$ & $\begin{array}{r}67 \\
57,26\end{array}$ \\
\hline healthy & 0,6024 & $\begin{array}{l}n \\
\%\end{array}$ & $\begin{array}{r}109 \\
50,00\end{array}$ & $\begin{array}{r}109 \\
50,00\end{array}$ & $\begin{array}{r}78 \\
54,55\end{array}$ & $\begin{array}{r}65 \\
45,45\end{array}$ & $\begin{array}{r}64 \\
54.70\end{array}$ & $\begin{array}{r}53 \\
45,30\end{array}$ \\
\hline attractive & 0,6500 & $\begin{array}{l}n \\
\%\end{array}$ & $\begin{array}{r}85 \\
38,99\end{array}$ & $\begin{array}{r}133 \\
61,01\end{array}$ & $\begin{array}{r}55 \\
38,46\end{array}$ & $\begin{array}{r}88 \\
61,54\end{array}$ & $\begin{array}{r}51 \\
43.59\end{array}$ & $\begin{array}{r}66 \\
56,41\end{array}$ \\
\hline the same as other people & 0,0958 & $\begin{array}{l}n \\
\%\end{array}$ & $\begin{array}{r}91 \\
41,74\end{array}$ & $\begin{array}{r}127 \\
58,26\end{array}$ & $\begin{array}{r}69 \\
48,25\end{array}$ & $\begin{array}{r}74 \\
51,75\end{array}$ & $\begin{array}{r}63 \\
53,85\end{array}$ & $\begin{array}{r}54 \\
46,15\end{array}$ \\
\hline \multicolumn{2}{|c|}{$\begin{array}{l}\text { What is the reaction of your community towards: } \\
\text { an underweight }\left(\mathrm{BMI} \leq 18,5 \mathrm{~kg} / \mathrm{m}^{2}\right) \text { person? }\end{array}$} & & \multicolumn{2}{|c|}{$\begin{array}{l}\text { Normal weight } \\
(n=218)\end{array}$} & \multicolumn{2}{|c|}{$\begin{array}{l}\text { Overweight } \\
(n=143)\end{array}$} & \multicolumn{2}{|c|}{$\begin{array}{c}\text { Obese } \\
(n=117)\end{array}$} \\
\hline They think they are: & $p$ & & YES & NO & YES & NO & YES & NO \\
\hline rich & 0,1873 & $\%$ & $\begin{array}{r}49 \\
22,48\end{array}$ & $\begin{array}{r}169 \\
77,52\end{array}$ & $\begin{array}{r}21 \\
14,69\end{array}$ & $\begin{array}{r}122 \\
85,31\end{array}$ & $\begin{array}{r}23 \\
19,66\end{array}$ & $\begin{array}{r}94 \\
80,34\end{array}$ \\
\hline healthy & 0,0225 & $\%$ & $\begin{array}{r}78 \\
35,78\end{array}$ & \begin{tabular}{r|}
140 \\
64,22
\end{tabular} & $\begin{array}{r}39 \\
27,27\end{array}$ & $\begin{array}{r}104 \\
72,73\end{array}$ & $\begin{array}{r}51 \\
43,59\end{array}$ & $\begin{array}{r}66 \\
56,41\end{array}$ \\
\hline attractive & 0,2041 & $\begin{array}{l}\mathrm{n} \\
\%\end{array}$ & $\begin{array}{r}82 \\
37,61\end{array}$ & $\begin{array}{r}136 \\
62,39\end{array}$ & $\begin{array}{r}44 \\
30,77\end{array}$ & $\begin{array}{r}99 \\
69,23\end{array}$ & $\begin{array}{r}48 \\
41,03\end{array}$ & $\begin{array}{r}69 \\
58,97\end{array}$ \\
\hline the same as other people & 0,0054 & $\begin{array}{l}n \\
\% \\
\%\end{array}$ & $\begin{array}{r}85 \\
38.99\end{array}$ & $\begin{array}{r}133 \\
61,01 \\
\end{array}$ & $\begin{array}{r}68 \\
47,55\end{array}$ & $\begin{array}{r}75 \\
52,45\end{array}$ & $\begin{array}{r}67 \\
57,26 \\
\end{array}$ & $\begin{array}{r}50 \\
42,74\end{array}$ \\
\hline
\end{tabular}

Table 8 represents the respondents' perceptions of health, weight and attractiveness related to three BMI groups (normal weight, $n=218$, overweight, $n=143$, obese, $n-117)$.

Healthy appearance A large percentage of the normal weight, overweight and obese respondents indicated that the overweight person was seen as the healthiest $(26,6 \%, 33,6 \%, 35 \%$ respectively $)$.

Acceptable weight When asked which person looks acceptable (normal weight) $31 \%$ of the normal weight and $32 \%$ of the obese respondents indicated that the figure depicting overweight was most acceptable. Thirty eight percent of the overweight respondents reported that lower normal weight was most acceptable.

Attractiveness The normal weight and obese respondents stated that the lower normal weight was most attractive $(31 \%$ and $32 \%$ respectively), while the overweight respondents (31\%) chose overweight as most attractive.

Perceptions of the respondents about the reaction towards obese and underweight persons related to $\mathrm{BMI}$ of respondents

Table 9 represents the respondents' perceptions about the reaction towards obese and underweight persons related to $\mathrm{BMI}$ of respondents. Almost half of the normal weight $(49 \%)$ and overweight respondents $(52 \%)$ indicated that the an obese person was seen by the community as not being rich. A slightly higher percentage $(57 \%)$ of obese respondents responded in this way. The same pattern occurred concerning the perceptions about the health of an obese person. Fifty percent of the normal weight, $55 \%$ of overweight and obese respondents reported that an obese person is seen by the community as healthy. The normal weight, overweight and obese respondents all agreed that, in the eyes of the community, an underweight person was not seen to be rich $(78 \% 85 \%$ and $80 \%)$. Most of the overweight respondents indicated that underweight is considered to be unhealthy and unattractive ( $73 \%$ and $69 \%$ respectively).

\section{DISCUSSION}

In this study a tool for the objective measurement of black South African women's perceptions of body size and community attitudes towards body size was developed. The computer program used to develop the tool uses a relatively simple and quick technique to produce a series of distortions of a scanned photograph. An expert panel of registered dieticians assigned a specific BMl to each photograph. Photograph 2, which represents a BMI of the lower range of normal weight $(18,5-19,9 \mathrm{~kg} / \mathrm{m} 2)$ showed the highest incorrect ratings, with six experts differing by more than $0,1 \mathrm{~kg} / \mathrm{m} 2$. However, the BMl ranges represented by photograph 2 (lower range of normal weight) and photograph 3 (higher range of normal weight) are still within the normal weight range as classified by the WHO (Mahan \& Escott-Stump, 2000:493). The photographs thus proved to be valid reproductions of the BMl's they were intended to portray.

The limitations of this method of producing images should, however, be recognised. If the body size is enlarged horizontally to a greater extent than that in photograph 5 without changing the height, the photographic image seems unreal. All obesity classifications (Mahan \& Escott-Stump, 2000:493) could thus not be represented, and the range of photographs 
included only one obese image that was classified as $\mathrm{BMl}>30 \mathrm{~kg} / \mathrm{m} 2$. Furthermore, this method relies on an image of the whole body and introduces an equal amount of distortion to all body parts. The photographic images of body size, like most other techniques, include only one view (frontal view) and do not allow subjects to form a holistic picture of the body. Showing all the other views would imply many more photographic images, which would extend the test, with a risk of participants losing interest.

Reliability of a research tool refers to the consistency with which a measuring instrument yields a certain result when the entity being measured has not changed (Leedy \& Ormond, 2005:29). Collins (1987) remarked that reliability data are rarely reported for measures of body image. Garner and Garfinkel (1981) reported reliable self-estimates using distorted photographs after one week of $r=0,75$ for anorexics and $r=0,45$ for controls. In our study the reliability data showed that most measures were stable over time. To keep the test relatively simple the questionnaire was short. Only three questions in the structured questionnaire were proved unreliable and were discarded. Body sizes that the respondents perceived as most healthy, most attractive, fat, normal and slim were consistent and confirmed as reliable to use with the photographs in the study population. The statement "Think they are lazy and do not like them" (4E and $5 \mathrm{E}$ ) had to be eliminated, as two concepts were asked in the same question and gave rise to conflicting answers. Confusion also arose with respect to the statement "Laugh at them", as it was often interpreted as "To laugh with them". Furthermore, the statement "Avoid them socially" seemed to be a culturally unacceptable concept in the sample population. Even though interpreters were used, differences in cultural concepts seemed to be the main reason why some questions in the questionnaire were unreliable and would have to be excluded from future studies among black South African women.

The only statistically significant differences between the younger and older groups were that a larger percentage of the younger women viewed normal weight as the healthiest $(p=0.0156)$, as well as acceptable $(p=0,0049)$, whereas a large percentage of the older women viewed the underweight as underweight $(p=0,0329)$, and the lower normal weight as acceptable $(p=0,0417)$.

In both age groups significantly higher percentages of respondents viewed the obese person as rich and healthy $(p<0,0002)$ compared to the underweight person.

No statistically significant differences were found between the normal weight, overweight and obese groups of women regarding which person looks the healthiest $(p=0,06)$.

A statistically significant difference between the normal weight, overweight and obese groups was found regarding which was the most acceptable weight to be $(p=0,01)$ with more obese women choosing normal weight as acceptable than overweight women.
A statistically significant difference between the normal weight, overweight and obese groups was found regarding this question, with more overweight women indicating that the underweight body was considered unhealthy $(p=0,01)$.

Change in appearance-related, weight and health values may happen from an individual level or at a macro level (Miller \& Pumariega, 2001). Thus, selfperception and cultural factors in African groups might serve as risk factors for health problems, such as obesity. In this study, the BMI measurement profile revealed that more than one-third of the subjects belonged to the normal weight category $(38 \%)$, and that more than $50 \%$ of the women were overweight or obese.

Our study supports the findings from earlier studies (Kruger et al, 1994) that an overweight body is considered to be the healthiest. It was found that the photograph depicting normal weight was fairly unpopular in terms of health.

More than half of the respondents asserted that, according to their experience, the community also perceived obese people as healthy. Underweight people were considered to be in poor health in the opinion of the community. Once again this is not in accordance with Western standards. In this study, health and slenderness were not linked together by most black women, even though the vast majority $(67,7 \%)$ selected a thin body size as healthy.

Cultural differences in perception of body weight have been well documented (Akan \& Grillo, 1995; Cachelin et al, 2002; Freedman \& Carter, 2007). Research has shown that African-American females are less concerned with weight, dieting, or being thin (Abrams et al, 1993; Akan \& Grillo, 1995; Hertzberger \& Molloy, 1998). Females would rather be "a little overweight" than "a little underweight". Black community health workers in South Africa revealed that they would be more attractive and healthier when they were thin, but that other women in their community would look better and more attractive when they were fat (Puoane et al, 2005). The results of the current study seem to support this data, indicating that culture plays an important role in body size perception. These results showed that $27,6 \%$ of the participants perceived normal weight as acceptable. Almost a third of the respondents believed that the lower normal weight and overweight figure was acceptable, respectively. Clearly, these aspects have different implications.

In western societies where thinness is regarded as a norm for beauty, young women are especially vulnerable to dissatisfaction with their body shape, and are more prone to developing eating disorders (Cooper, 1995:32-36; Cogan et al, 1996). South African studies postulates that black women were dissatisfied with their weight, but valued an overweight woman at the same time as more desirable. (Senekal et al, 2001; Puoane et al, 2005). On the one hand these women are exposed to the media, which portray thin women as attractive. On the other hand they want to be what they are supposed to be according to their own cul- 
tural values, and thus become confused. In our study, when respondents were asked to choose the body they perceived as being most attractive, the majority of respondents chose the lower normal weight and overweight bodies as most attractive. Slightly more individuals indicated that the body of lower normal weight was attractive.

A number of studies have shown that, compared to Caucasian women, non-Westernised and some groups of Westernised African women, have adopted a larger ideal body size. They did not necessarily perceive overweight as unattractive, and were therefore less likely to aspire to thinness (Greenberg \& La Porte, 1996; Toriola et al, 1996; Wilfley et al, 1996). The current study supports this view, as it was found that $63,7 \%$ participants believed that the community would find an underweight person unattractive.

When respondents were asked whether or not the community viewed obese people as being attractive, approximately $40 \%$ agreed. This is also very different from the Western viewpoint where obesity is considered to be unattractive. Beauty norms differ in societies, and the stigma of fatness being ugly is far from a universal value. Kumanyika et al (1993), drawing from a sample of African American women aged 25-64 years $(n=55)$, found that about $40 \%$ of the women in the overweight categories, based on BMI, considered their figures to be attractive.

It is believed that certain cultural factors drive the standards of desirable body weight within cultures. For example, traditional Polynesian societies see obesity as a sign of good health, wealth, prestige, beauty and high social ranking (Matangi et al, 1995). In the current study, almost half the members of both age groups considered that an obese person was wealthy. By Western standards this observation was remarkable, since the Western view on health and wealth is totally different. One possible reason for this phenomenon could be that many respondents viewed being rich as being able to afford a lot of food. In a study amongst African women (18-36 years) in periurban Cape Town, an increased body mass was also perceived by some as an indication of wellbeing (Mvo et al, 1999). Powers (1988:6-16) suggested that in some cultures, obesity was admired, and that these cultures valued obesity as a symbol of success and economic security.

A study done by Pickett, (2007) showed that only 15 percent of obese respondents (sample - 104 adults) viewed themselves as obese. In this study $32 \%$ of respondents indicated that overweight is seen as normal weight.

Most respondents in this study felt that their community considered thinner people to be poor. Traditionally, a high circumference was seen as a sign of prosperity and health, while a skinny frame meant that a person was too poor to afford enough to eat (Powers, 1996). During the twentieth century these views have been reversed in most developed countries. However, in less-developed countries where food security is frequently still uncertain, fatness still appeared to be a sign of prestige (Powers, 1996).

\section{CONCLUSIONS AND RECOMMENDATIONS}

A valid and reliable tool, specifically to provide quantitative information on perceptions of body size amongst black South African women, was developed. Understanding the individual's perception of his/her own body size and the community's perception towards obesity might allow the health professional greater insight with regard to planning preventive interventions.

According to the results, it could be concluded that the overweight body was mostly preferred in terms of attractiveness and that health could be related to larger body size, unlike the view held by the Western culture. This study also showed that social interventions to address obesity should be based on education programmes designed to change the population's beliefs as far as the relationship between obesity on the one hand, and status and health on the other, is concerned.

The data in this study further indicated that the respondents' perceptions were influenced by cultural and social factors. However, it could also have been a matter of these women having a culturally influenced view of body weight. They might benefit from culturally relevant programmes that could help them link weight to health rather than to the dominant Western standards of thinness.

Western methods commonly used to lose weight, such as food deprivation and increased physical activity by vigorous exercise, need to be adapted to include cultural food patterns, cultural meanings of ideal weight, and increased physical activity in the daily routine.

Further research in this area should include a wider age range in order to differentiate between women in different age categories, and should include both urban and rural women to differentiate between their views and opinions.

\section{REFERENCES}

ABRAMS, KK, ALLEN, LR \& GRAY, JJ. 1993. Disordered eating attitudes and behaviors, psychological adjustment, and ethnic identity: A comparison of black and white female college students. International Journal of Eating Disorders 14(1):49-57.

AKAN, GE \& GRILLO, CM. 1995. Socio-cultural influences on eating attitudes and behaviors, body image, and psychological functioning: A comparison of African-American, Asian-American, and Caucasian college women. International Journal of Eating Disorders 18(2):181-187.

BJÖRNTORP, P. 2001. Obesity - an overview of obesity as a disease with many risks for morbidities. Continuing Medical Education 19(8):552-556.

CACHELIN, FM, REBECK, RM, CHUNG, GH \& PELAYO, E. 2002. Does ethnicity influence body-size preference? A comparison of body image and body size. Obesity Research 10(3):158-166.

CASH, TF \& PRUZINSKY, T. 2002. Future challenges for body image theory, research, and clinical 
practice. In Cash, TF \& Pruzinsky, T (eds). Body Image: A handbook of theory, research, and clinical practice. New York. Guilford Press.

CHABI, R, KHALDOUNE, J, BOUR, A, BELAHSEN, L, LAHLOU, H, AGUENAOU, H \& MOLCHTAR, N. 1998. Determination of anthropometric, biological, clinical and nutritional characteristics of obese women from an agricultural region from Morocco. International Journal of Obesity 22:S212

CLARK, FA, MICCOLAI, L, KISSINGER, PJ PETERSON, Y, BOUVIER,V. 1999. Ethnic differences in body image attitudes and perceptions among women infected with human immunodeficiency virus. Journal of the American Dietetic Association 99: 735-737. COGAN, C, BHALLA, SK, SEFAS-DEDEH, A \& ROTHBLUM, ED. 1996. A comparison of United States and African students on perceptions of obesity and thinness. Journal of Cross-Cultural Psychology 27(1):98-113.

COLLINS, JK. 1987. Methodology for the objective measurement of body image. International Journal of Eating Disorders 6(4): 393-399.

COOPER, Z. 1995. The development and maintenance of eating disorders. In Brownell, KD \& Fairburn, CG (eds). Eating disorders and obesity: a comprehensive handbook. New York. Guilford Press.

DAWSON, D. 1988. Ethnic differences in female overweight: Data from the 1985 National Health Interview Survey. American Journal of Public Health 78 (10):1326-1329.

FREEDMAN, EK \& CARTER, MM. 2007. Do men hold African-American and Caucasian women to different standards of beauty? Eating Behaviors 8 (3):319-333.

GARNER, DM \& GARFINKEL, PE. 1981. Body image in anorexia nervosa: Measurement, theory and clinical implications. International Journal for Psychiatry Medicine 11: 263-284.

GOEDECKE, JH, JENNINGS, CL, LAMBERT, EV. 2006. Obesity in South Africa, In Steyn, K, Fourie, J \& Temple, N (eds). Chronic Diseases of Lifestyle: 19952005. Technical report. Cape Town: South African Medical Research Council???.

GREENBERG, DR \& LA PORTE, DJ. 1996. Racial differences in body type preferences of men for women. International Journal of Eating Disorders 19 (3):275-278.

HERZBERGER, SD \& MOLLOY, BL. 1998. Body image and self-esteem: A comparison of African American and Caucasian women. Sex Roles 38 (6/7):631-643.

HOFFMAN, M, PICK, WM, COOPER, D \& MEYERS, E. 1997. Women's health status and use of health services in a rapidly growing peri-urban area of South Africa. Social Science and Medicine 45(1):149-157.

KALK, WJ. 2001. Epidemiology of obesity: Where do we stand in terms of obesity in South Africa? Continuing Medical Education 19(8):576-578.

KIM, S, MOON, S \& POPKIN, BM. 2000. The nutrition transition in South Korea. Journal of Clinical Epidemiology 71(1):44-53.

KRUGER, HS, VAN AARDT, AM, WALKER, ARP \& BOSMAN, MJC. 1994. Obesity in African hypertensive women: Problems in treatment. South African Journal of Food Science and Nutrition 6(3):103-107. KUMANYIKA, SK, WILSON, JF \& GUILDFORD-
DAVENPORT, M. 1993. Weight related attitudes of Black women. Journal of the American Dietetic Association 93:416-422.

LEAN, MEJ, HAN, TS \& MORRISON, CE. 1998. Waist circumference as a measure for indicating need for weight management. British Medical Journal 311 (6998):158-161.

LEEDY, PD \& ORMROD, JE. 2005. Practical Research $\left(8^{\text {th }}\right.$ ed.). New Jersey. Upper Saddle River. Merrill, Prentice Hall

MACINTYRE, UE. 1998. Dietary intakes of Africans in transition in the North-West Province. Thesis (PhD) Potchefstroom University for Christian Higher Education. Potchefstroom.

MAHAN, KL \& ESCOTT-STUMP, S. 2000. Krause's food, nutrition and diet therapy. $10^{\text {th }}$ Edition. Philadelphia. WB Saunders Company.

MASSARA, EB \& STUNKARD, AJ. 1979. A method of quantifying cultural ideals of beauty and the obese. International Journal of Obesity 3 (4): 149-152.

MATANGI, H, SWINBURN, B, CRAIG, P, MATEGASMITH, T \& VAUGHAN, G. 1995. Do Pacific Islanders still believe that "Big is Beautiful"? Body size perceptions among Cook Islanders. Asia Pacific Journal of Clinical Nutrition, 4(1):368.

MILLER, MN \& PUMARIEGA, AJ. 2001. Culture and eating disorders: A historical and cross-cultural review. Psychiatry: Interpersonal and Biological Processes 64(1):93-100.

MVO, Z, DICK, J, STEYN,K. 1999. Perceptions of overweight African women about acceptable body size of women and children. Curationis 22(2):27-31.

PICKETT, M. 2007. Obese people lack health awareness. http://www.healthline.com/sw/bar-study-obesepeople-lack-health-awareness (Retrieved on 29 July 2009)

POPKIN, B. 2001. The Nutrition transition and obesity in the developing world. Journal of Nutrition 131:871873.

POWELL, AD, KAHN, AS. 1995. Racial differences in women's desires to be thin. International Journal for Eating Disorders 17, 191-195 [Medline].

POWERS, PS. 1988. Social Issues in Obesity. In Burrows, G, Beaumont, PJV \& Casper, RC (eds). Handbook of Eating Disorders: Part 2: Obesity. Amsterdam. Elsevier.

POWERS, PS. 1996. In the eye of the beholder. $\mathrm{Hu}$ man Ecology 24(4):16-20.

PRENTICE, AM. 2000. Epidemic obesity and diabetes in developing countries. Paper presented at the symposium on "Obesity in Poverty and Affluence", hosted by the South African Sugar Association, CSIR, Pretoria, South Africa, February 2000.

PUOANE, T, STEYN K, BRADSHAW, D. 2002. Obesity in South Africa: The South African demographic and health survey. Obesity Research 10: 1038-1048.

PUOANE, T, FOURIE, JM, SHAPIRO, M, ROSLING, L, TSHAKA, NC, OELEFSE, A. 2005. "Big is beautiful" - an exploration with urban black community health workers in a South African township. South African Journal of Clinical Nutrition 18(1):6-15.

REBOUSSIN, B, REJEKSI, WJ, MARTIN, K, CALLAHAN, K, DUNN, A, KING, A \& SALLIS, J. 2000. Correlates of satisfaction with body function and body appearance in middle- and older aged adults: The activity counseling trial (ACT). Psychology and Health 
15(4):239-254.

SENEKAL, M, STEYN, NP, MASHEGO, TV, NEL, JH. 2001. Evaluation of body shape, eating disorders and weight management related parameters in Black female students of rural and urban origins. South African Journal of Psychology 31:45-53.

SHAW, H, RAMIREZ, L, TROST, A, RANDALL, P \& STICE, E. 2004. Body image and eating disturbances across ethnic groups: More similarities than differences. Psychology of Addictive Behaviours 18(1):1218.

SLABBER, M; LAUBSCHER, M; VAN DEN HEEVER, C \& JOUBERT, G. 2000. Ideals and perceptions of body size of first year female students at the UOFS. Journal for. Endocrinal Metabolism Diabetes, SouthAfrica, 5: 64.

STEVENS, J, KUMANYIKA, SK \& KEIL, JE. 1994. Attitudes toward body size and dieting: Differences between elderly black and white woman. American Journal of Public Health 84(8):1322-1325.

TORIOLA, AL, DOLAN, BM, EVANS, C \& ADETIMOLE, O. 1996. Weight satisfaction of Nigerian women in Nigeria and Britain: Inter-generational and cross-cultural influences. European Eating Disorders Review 4(2):84-94.

WALKER, ARP \& SEGAL, I. 1997. Health/ill-health transition in less privileged populations: what does the future hold? Journal of the Royal College of Physicians of London 31(4):392-395.

WILFLEY, DE, SCHREIBER, GB, PIKE, KM, STRIEGEL-MOORE, RM, WRIGHT, DJ \& RODIN, J. 1996. Eating disturbance and body image: A comparison of a community sample of adult Black and White women. International Journal of Eating Disorders 20 (4):377-387. 